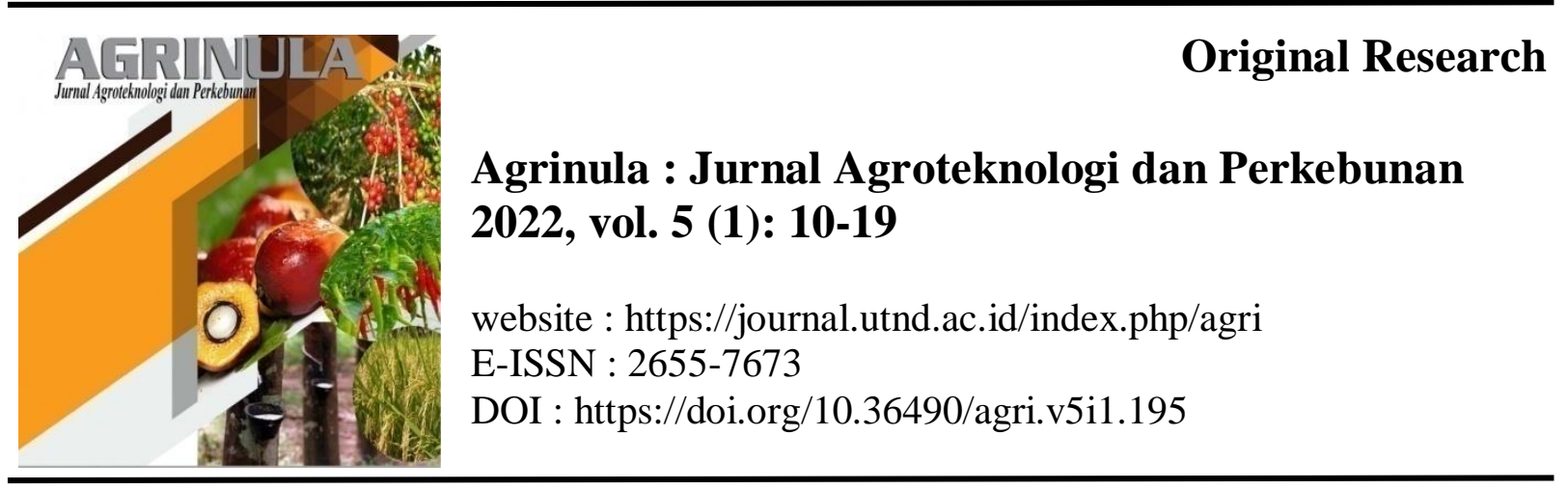

\title{
QUANTIFYING PHYSICOCHEMICAL PROPERTIES OF HONEY COLLECTED FROM DIFFERENT FLORAL SOURCES OF ISLAMABAD AND MARDAN REGIONS
}

\section{Komal Tariq ${ }^{1}$, Sabir Iqbal ${ }^{2}$, \& Muhammad Fraz $\mathrm{Ali}^{3 *}$}

${ }^{1}$ College of Life Sciences, Agriculture and Forestry, Qiqihar University, Heilongjiang 161000, China.

${ }^{2}$ Department of Agriculture, Faculty of Chemical and Life Sciences, Abdul Wali Khan University Mardan, Khyber Pakhtunkhwa 23200, Pakistan.

${ }^{3}$ College of Agronomy, Northwest A \& F University, Yangling Shaanxi 712100, China. *Corresponding author: frazali15@gmail.com

\begin{tabular}{|c|c|}
\hline Article Information & ABSTRACT \\
\hline $\begin{array}{l}\text { Revised: } \\
\text { December 08, } 2021 \\
\text { Accepted: } \\
\text { December 09, } 2021 \\
\text { Published: } \\
\text { December 14, } 2021\end{array}$ & $\begin{array}{l}\text { - Introduction: Honeybee (Apis mellifera L.) is known } \\
\text { for pollination and honey production. There are some } \\
\text { physicochemical properties through which the honey } \\
\text { identifies. The current study was aimed to study the } \\
\text { physiochemical characteristics of different honey sources } \\
\text { collected from Islamabad and Mardan districts of } \\
\text { Pakistan according to the prescribed international } \\
\text { standards. } \\
\text { Materials and Methods: This study was conducted in } \\
\text { Honey Analysis Laboratory, Honey Bee Research } \\
\text { Institute (HBRI), National Agriculture Research Center } \\
\text { (NARC) Islamabad, to evaluate the physicochemical } \\
\text { properties of honey collected from different floral } \\
\text { sources of Islamabad and Mardan regions. The total of } \\
12 \text { honey samples of A. mellifera L. were tested. In this } \\
\text { study } 12 \text { honey samples were collected from beekeepers } \\
\text { of Islamabad and Mardan area. Physicochemical analysis } \\
\text { such as moisture content, pH, electrical conductivity, } \\
\text { free acidity, total soluble solids, density and pollen } \\
\text { analysis were carried out. } \\
\text { Results: showed that some of the samples have high }\end{array}$ \\
\hline
\end{tabular}




\begin{tabular}{|l|l|}
\hline & $\begin{array}{l}\text { value for moisture, } \mathrm{pH} \text { and electrical conductivity while } \\
\text { the other parameters were in normal range. Results of the } \\
\text { physicochemical properties show the following range of } \\
\text { values for moisture content }(1.36-1.55 \%), \mathrm{pH}(3.72- \\
6.61), \mathrm{EC}(0.1-1.1), \text { acidity }(10-30 \mathrm{meq} / \mathrm{kg}), \text { total sugars } \\
\text { (76.2-78.8\%), density }(1.23-1.46 \mathrm{~kg} / \mathrm{l}), \text { and pollen } \\
\text { analysis showed multiple floral samples. } \\
\text { Keywords: floral sources; honey samples; physicochemical } \\
\text { properties }\end{array}$ \\
\hline
\end{tabular}

\section{INTRODUCTION}

Honey is a delightful sticky sweetener made naturally by bees for their own food from the flower's secretion or nectar (Howes, 2013). It is used as sweeteners and flavoring agents in both alcoholic and non-alcoholic drinks and in confectionaries (Miele et al., 2017). Beekeeping is the practice which is adapted to protect bee colonies (Decourtye et al., 2019) and it is also considered as an important agricultural activity for getting honey and earning a lot of revenue from it (Mohammed et al., 2017). In the genre Apis, the majority bees are honey bees and honey bees are known for honey production, pollens, bee venom, wax, propolis and other goods. Besides honey, bees wax, pollen and royal jelly are used in medicines, foodstuffs and other goods (Kampmeier \& Irwin, 2009). Honey bees have medical and nutritional benefits and they are also responsible for economic importance for the pollination of agricultural crops (Payne \& Van Itterbeeck, 2017). More than $90 \%$ of food crops depend heavily on the pollination services of honeybees. There are four species of honeybee which are present in Pakistan, from which two are wild A. dorsata and A. florea and two are domesticated A. cerana and A. mellifera. A. mellifera L. (Noor et al., 2009). Geographical and environmental factors are the key components which affects quality and composition honey (Pohl et al., 2012). The quality and properties of honey are associated and linked to maturity of honey bee, producing methods, climatic conditions, processing and storage conditions as well as nectar sources of the honey (Guler et al., 2007). Global climate change is disturbing the quality of honey throughout the globe.

Honey is usually evaluated through physicochemical properties of its constituents. Physicochemical parameters like moisture, acidity, $\mathrm{pH}$, hydroxymethylfurfural (HMF) content, color, sugar composition and specific conductivity of the natural honey are precisely defined and each characteristic is known to represent quality indicators and is reported by many scientist (Kahraman et al., 2010; Ndife et al., 2014; Gobessa et al., 2012; Sajid et al., 2020; Kumar et al., 2018). Honey is also well known natural cheaper source of essential inorganic elements for consumers which are required for body metabolism (Al-Waili, 2003). Honey quality has a great impact on texture, flavor, granulation, shelf life and nutritional quality of honey. The current study was aimed to study the physiochemical characteristics of different honey sources collected from Islamabad and Mardan districts of Pakistan according to the prescribed international standards. 


\section{MATERIALS AND METHODS}

\section{Collection of Honey Samples}

A total of twelve honey samples were collected from beekeepers from the different locations of Islamabad and Mardan during the March-April, 2020. Honey samples were stored in sealed plastic jars followed by labeling and dating and kept at the room temperature $\pm 29^{\circ} \mathrm{C}$ till completion of analysis. All these honey samples were classified on the basis of their dominant botanical and geographical origin.

\section{Physicochemical Analysis of Honey}

The study was completed in the Honey Analysis Laboratory of HBRI, NARC, Islamabad. A total of 12 honey samples of honeybee A. mellifera L. were examined in this study. Physiochemical examination of honey samples such as moisture content (\%), $\mathrm{pH}$, electrical conductivity $(\mathrm{mS} / \mathrm{cm})$, free acidity (meq/kg), total soluble solids $(\%)$, density (Baume) and pollen analysis was carried out by the international honey commission (Bogdanov et al., 1999).

\section{Determination of Moisture Content}

Moisture of honey must meet international standard $(21 \mathrm{~g} / 100 \mathrm{~g})$ and is the great cause of honey fermentation throughout the world. The moisture content influences some important characteristics of honey, such as viscosity and brix. Refractometer were used for the purpose of finding the moisture of honey. One drop of honey was taken on the glass surface of refractometer. The sample was covered on the surface of the prism evenly; after two minutes the reading of refractive index was recorded from the lens with the help of eyes.

\section{Determination of $\mathrm{pH}$}

$\mathrm{pH}$ is another important parameter during extraction and the conservation of honey. It increases the quality, constancy and shelf life of honey (Terrab et al., 2002). $\mathrm{pH}$ of 12 honey samples was calculated by $\mathrm{pH}$ meter. The $\mathrm{pH}$ meter was standardized with standard buffer solution of $\mathrm{pH} 4$ and 7. 10 gram of honey sample was taken and liquefy in $75 \mathrm{ml}$ distilled water in beaker of $250 \mathrm{ml}$. Solution was stirred and $\mathrm{pH}$ electrode was immersed in it, when meter got stable, $\mathrm{pH}$ was recorded directly from meter.

\section{Determination of Density}

The density was recorded relationship of weight to volume ratio. $1 \mathrm{ml}$ of sample was poured into $5 \mathrm{ml}$ cylinder with the help of a dropper. Weight was measured with laboratory electric balance. Following equation was used for density calculation (Bettelheim \& Landsberg, 2012):

$$
\text { Density }=\frac{\lfloor(\text { Mass of honey }+ \text { cylinder })-(\text { mass of cylinder })\rfloor}{\text { Volume of honey }}
$$




\section{Acidity Determination}

Honey (10 g) was weighed with the help of digital analytical balance and dissolved into $75 \mathrm{ml}$ distilled water. Phenolphthalein $1 \%$ was used as an indicator. In solution about 4-5 phenolphthalein drops were putted. Then measured beside the solution of $0.1 \mathrm{M} \mathrm{NaOH}$ with burette. The titration was carried out till the solution turns to pink from colorless. The acidity was determined by using formula:

Percentage acidity $(\%)=$ volume of $\mathrm{NaOH}$ used $\times$ honey weight

\section{Electrical Conductivity (EC) Calculation}

A conductivity meter (Model 315i, WTW instruments Wilhelm, Germany) was used for finding the EC. Distilled water was used to adjust EC Meter after that in $10.0 \%$ solution the conducting Cells were putted and when meter got stable EC recorded. 10 grams of honey took in beaker and added $75 \mathrm{ml}$ distilled water. Solution was dissolved well before reading was taken.

\section{Pollen Test}

The pollen test of honey was studies according to $10 \mathrm{~g}$ of honey was taken in a conical flask. $20 \mathrm{ml}$ of distilled water were added to dissolved the honey in flask. Labeled the sample, then solution was poured in the centrifuge tubes. The centrifuge tubes were then put in the centrifuge in proper balance. The centrifuge was then set at $3000 \mathrm{rpm}$ for 20 minutes. After centrifugation of honey solution, the supernatant liquid was discarded and only the sediment was taken for pollen analysis with the help of droppers. Then the pollen sediments were spread on the slide to check under a compound microscope. The botanical origin of the honey was studied by using the techniques described by Maurizio, (1975). Slides were prepared by acetolysis by centrifuging $10 \mathrm{~g}$ of honey dissolved in $20 \mathrm{~mL}$ of diluted sulfuric acid ( $5 \mathrm{~g} \mathrm{H}_{2} \mathrm{SO}_{4} \mathrm{~L} 71$ ) for $10 \mathrm{~min}$ at $2500 \mathrm{rpm}$. The supernatant was decanted and the sediment washed twice with $10 \mathrm{~mL}$ distilled water and then centrifuged. The sediment was extended on a slide and dried at $70-80{ }^{\circ} \mathrm{C}$, then mounted with stained glycerine gelatin. Pollen grains were identified and counted by using a microscope model BH-2 (Olympus Optical Ltd, Tokyo, Japan) at a magnification of 6200. After pollen grains were counted, they were classified in the following frequency classes: Predominant pollen (445\% of the pollen grains counted); secondary pollen (16-45\%); important minor pollen (3-15\%), and minor pollen (53\%), according to Louveaux et al., (1978).

\section{Statistical Analysis}

All analysis was carried out in triplicate and the data were expressed as means which was calculated by using Excel (Microsoft Office, version 2013). Standard errors are also calculated and errors bars are assigned to every sample. 


\section{RESULTS AND DISCUSSION \\ Physicochemical Analysis of Honey}

The results for physicochemical properties of honey samples collected from Islamabad and Mardan hills are given below in the Figure 1. Figure 1A shows the data for moisture content percentage (MC \%), in MC \% many factors which includes floral season, degree of maturity and ecological factors determines the moisture contents of honey. Maximum moisture content of honey sample is obtained from Islamabad as $21.9 \%$ and it ranges from (19.2-21.9\%) while for minimum moisture content is obtained from Mardan as $17 \%$ and it ranges from (17-20.9\%). According to honey standards set by the Pakistan Standard and Quality Control Authority (PSQCA) and codex, the moisture content of the study area's honey falls under the Grade 'A' category. Density tells us about the glucose contents present in honey at commercial scale. Honey samples with high density have great contents of glucose. In current experiment high density was recorded in Mardan samples and the overall range for density of 6 samples for both regions varies from (1.23-146 kg/l) as show in Figure 1B. Total sugars percentage range from (76.2-78.6\%) for samples of both region as show in Figure 1C. $\mathrm{pH}$ is an important parameter during extraction and preservation of honey as it raises the shelf life, quality and reliability of honey. $\mathrm{pH}$ of different samples obtained from Islamabad and Mardan was given in Figure 1D. Maximum and minimum $\mathrm{pH}$ is obtained from honey samples of Mardan as it ranges from (3.72-6.61) while Islamabad honey samples $\mathrm{pH}$ range varies from (3.80-5.24). Islamabad honey samples is more acidic in nature as compared to samples of Mardan. $\mathrm{pH}$ of honey samples from Islamabad and Mardan lies under the standard category of PSQCA and Codex as given in Table 1. For honey electrical conductivity (EC) depends upon on mineral contents, inorganic ions, organic acids contents and also some sugar complexes and varies with botanical origin. EC is used for detection of quality and purity of honey. For the current sampling of honey EC is shown Figure 1E. Range of EC for honey samples for both regions have a significant difference and it have range from $(0.1-1.1) \mathrm{mS} \mathrm{cm}^{-1}$.

Table 1. Physiochemical properties of honey with PSQCA and CODEX Standard

\begin{tabular}{lll}
\hline \multicolumn{1}{c}{ Physiochemical parameter } & PSQCA Standard range & Codex standard range \\
\hline Moisture & Not more than $21 \%$ & Not more than $20 \%$ \\
Reducing sugars & Not less than $65 \%$ & Not less than $60 \%$ \\
Apparent Sucrose & Not more than $5 \%$ & Not more than $5 \%$ \\
$\mathrm{pH}$ & $3.0-6.40$ & $3.0-6.40$ \\
Acidity & Lesser from $40 \mathrm{Meq} / \mathrm{kg}$ & Lesser from $50 \mathrm{Meq} / \mathrm{kg}$ \\
Electrical Conductivity & Lesser from $0.8 \mathrm{Ms} / \mathrm{cm}$ & Lesser from $0.8 \mathrm{Ms} / \mathrm{cm}$ \\
$\mathrm{HMF}$ & Lesser from $80 \mathrm{Mg} / \mathrm{kg}$ & Lesser from $40 \mathrm{Mg} / \mathrm{kg}$ \\
Diastase (after blending & Must not be greater from & Must not be greater \\
processing) & 3 Shade Units & from 8 Shade Units \\
Ash & Lesser from $0.6 \%$ & Not more than $0.6 \%$ \\
Water insoluble solid contents & Not more than $0.1 \%$ & Not more than $0.1 \%$ \\
\hline
\end{tabular}



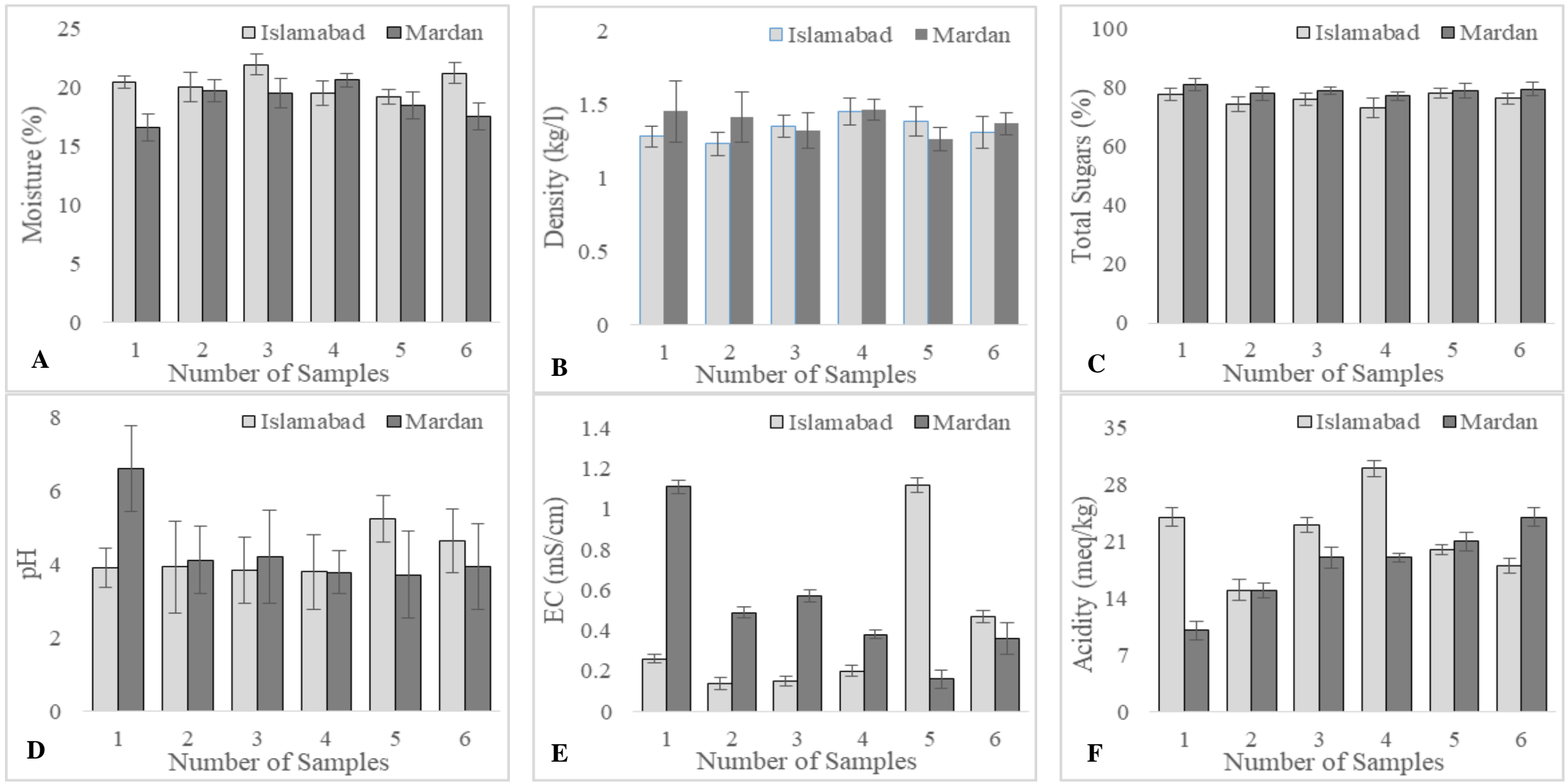

Figure 1. Physiochemical properties of honey bees samples collected from Islamabad and Mardan, $\mathrm{A}=$ moisture percentage; $\mathrm{B}=\mathrm{density}$ percentage; $\mathrm{C}=$ total sugars percentage; $\mathrm{D}=\mathrm{pH} ; \mathrm{E}=$ electrical conductivity; $\mathrm{F}=$ acidity. 
There are few samples which are out from the PSQCA and Codex standard from our samples. Due to occurrence of inorganic ions and organic acids, honey is acidic in nature regardless of its origin. Acidity is valuable standard for assessment of honey fermentation and authentication of unifloral honeys. Acidity (meq $/ \mathrm{kg}$ ) for current experimentation is given in Figure 1F, Samples of Islamabad have range of acidity from 15 to $30 \mathrm{meq} / \mathrm{kg}$ and Mardan samples have range from 10 to $24 \mathrm{meq} / \mathrm{kg}$. Hence it shows that samples of Islamabad have more organic contents in it and acidic in their physical properties of taste and according to international standards our samples lies in group A for PSQCA and Codex as given in Table 1.

\section{Pollen Test}

The pollen of all samples were from medium to high except for one sample S-6 Mardan which showed no pollens. Pollen analysis revealed that some honeys had single flora as primary flora (Uni-floral) such as Sider, Acacia, while most of the samples showed mixed flora. Mardan Sider honey (S-1) sample showed good pollen density.

Table 2. Classification of pollen and pollen density for the studies samples of Islamabad and Mardan

\begin{tabular}{lcccc}
\hline & \multicolumn{2}{c}{ Pollen } & \multicolumn{2}{c}{ Pollen density } \\
\cline { 2 - 5 } & Islamabad & Mardan & Islamabad & Mardan \\
\hline S1 & Multi floral & Sider & High & Medium \\
S2 & Multi floral & Multi-flora & Medium & Medium \\
S3 & Multi floral & Acacia + Granda & High & Medium \\
S4 & Brassica, Wild flower & Acacia & Medium & High \\
S5 & Sider & Acacia & Low & High \\
S6 & Accacia, Granda & No pollen & Medium & None \\
\hline
\end{tabular}

\section{Discussion}

Honey composition and quality depends upon various factors such as, weather condition during honey production, composition of nectar, beekeeping practices and handling method during honey extraction and storage. For moisture content percentage our results are supported by the findings of Kumar et al., (2018); Al-Ghamdi et al., (2019) who reported that $18.35-22.1 \%$ and $18.50-20.2 \%$ water content in different honey samples and these are according to the standards of international organizations. Electrical conductivity (EC) belongs to mobility of electron and is linked with the presence of mineral salt, organic acid and protein levels in honey samples. Kaškonienè et al., (2010) reported that in many regions of "Lithuania" reported EC in floral honeys with range of 0.34 and $0.89 \mathrm{mS} \mathrm{cm}^{-1}$. High mineral contents in honey give us high amount of EC as reported by Alissandrakis et al., (2011). pH and acidity of honey depends upon the presence of organic acids specially gluconic acid as equal to lactones, esters and other chlorides and phosphates (Lanjwani, 2020). Our samples showed presence of organic acids and there range matches and supported by the results of Kinoo et al., (2012). Andrade et al., (1997) reported that composition of honey sugar totally 
depends upon with the floral and its region of origin. Our honey samples have different origins and also have multiple floral sources as give in Table 2.

\section{CONCLUSION}

The current study revealed that Pakistan, with its highly rich plant flora in hilly areas, is also rich in terms of honey diversity for both Islamabad and Mardan regions. Several types of honey of monofloral origin were compared in this study in addition to multifloral honeys, which investigate the physical and chemical characteristics and the results concluded that honey samples are according with PSQCA and codex standards.

\section{REFERENCES}

Al-Ghamdi, A., Mohammed, S. E. A., Ansari, M. J., \& Adgaba, N. (2019). Comparison of physicochemical properties and effects of heating regimes on stored Apis mellifera and Apis florea honey. Saudi Journal of Biological Sciences, 26(4), 845848. https://doi.org/10.1016/j.sjbs.2017.06.002.

Alissandrakis, E., Tarantilis, P. A., Pappas, C., Harizanis, P. C., \& Polissiou, M. (2011). Investigation of organic extractives from unifloral chestnut (Castanea sativa L.) and eucalyptus (Eucalyptus globulus Labill.) honeys and flowers to identification of botanical marker compounds. LWT-Food Science and Technology, 44(4), 10421051. https://doi.org/10.1016/j.lwt.2010.10.002.

Al-Waili, N. S. (2003). Effects of daily consumption of honey solution on hematological indices and blood levels of minerals and enzymes in normal individuals. Journal of Medicinal Food, 6(2), 135-140. https://doi.org/10.1089/109662003322233549.

Andrade, P., Ferreres, F., \& Amaral, M. T. (1997). Analysis of honey phenolic acids by HPLC, its application to honey botanical characterization. Journal of Liquid Chromatography \& Related Technologies, 20(14), 2281-2288. https://doi.org/10.1080/10826079708006563.

Bettelheim, F. A., \& Landesberg, J. M. (2012). Laboratory experiments for introduction to general, organic and biochemistry. Cengage Learning, United States.

Bogdanov, S., Lüllmann, C., Martin, P., von der Ohe, W., Russmann, H., Vorwohl, G., Oddo, L. P., Sabatini, A., Marcazzan, G. L., Piro, R., Flamini, C., Morlot, M., Lhéritier, J., Borneck, R., Marioleas, P., Tsigouri, A., Kerkvliet, J., Ortiz, A., Ivanov, T., D'Arcy, B., Mossel, B., \& Vit, P. (1999). Honey quality and international regulatory standards: review by the International Honey $\begin{array}{llll}\text { Commission. } \quad \text { Bee } & \text { World, }\end{array}$ https://doi.org/10.1080/0005772X.1999.11099428.

Decourtye, A., Alaux, C., Le Conte, Y., \& Henry, M. (2019). Toward the protection of bees and pollination under global change: present and future perspectives in a challenging applied science. Current Opinion in Insect Science, 35, 123-131. https://doi.org/10.1016/j.cois.2019.07.008.

Gobessa, S., Seifu, E., \& Bezabih, A. (2012). Physicochemical properties of honey produced in the Homesha district of Western Ethiopia. Journal of Apicultural Science, 56(1), 33-40. https://doi.org/10.2478/v10289-012-0004-z.

Guler, A., Bakan, A., Nisbet, C., \& Yavuz, O. (2007). Determination of important biochemical properties of honey to discriminate pure and adulterated honey with 
sucrose (Saccharum officinarum L.) syrup. Food Chemistry, 105(3), 1119-1125. https://doi.org/10.1016/j.foodchem.2007.02.024.

Howes, F. N. (2013). Plants and beekeeping-an account of those plants, wild and cultivated, of value to the hive bee, and for honey production in the british isles. Read Books Ltd.

Kahraman, T., Buyukunal, S. K., Vural, A., \& Altunatmaz, S. S. (2010). Physicochemical properties in honey from different regions of Turkey. Food Chemistry, 123(1), 41-44. https://doi.org/10.1016/j.foodchem.2010.03.123.

Kampmeier, G. E., \& Irwin, M. E. (2009). Commercialization of insects and their products. In Encyclopedia of Insects (pp. 220-227). Academic Press.

Kaškonienè, V., Venskutonis, P. R., \& Čeksterytè, V. (2010). Carbohydrate composition and electrical conductivity of different origin honeys from Lithuania. LWT-Food Science and Technology, 43(5), 801-807. https://doi.org/10.1016/j.lwt.2010.01.007.

Kinoo, M. S., Mahomoodally, M. F., \& Puchooa, D. (2012). Anti-microbial and physico-chemical properties of processed and raw honeys of Mauritius. Advances in Infectious Diseases 2(2), 1-12. http://dx.doi.org/10.4236/aid.2012.22005.

Kumar, A., Gill, J. P. S., Bedi, J. S., Manav, M., Ansari, M. J., \& Walia, G. S. (2018). Sensorial and physicochemical analysis of Indian honeys for assessment of quality and floral origins. Food Research International, 108, 571-583. https://doi.org/10.1016/j.foodres.2018.04.005.

Lanjwani, M. F. (2020). Investigation of antioxidant activity and physicochemical properties of local and branded honeys in Sindh, Pakistan. Sustainable Chemical Engineering, 1(1), 43-50. https://doi.org/10.37256/sce.11202079.43-50.

Louveaux, J., Maurizio, A., \& Vorwohl, G. (1978). Methods of melissopalynology. Bee World, 59(4), 139-157. https://doi.org/10.1080/0005772X.1978.11097714.

Maurizio, A. (1975). Microscopy of honey. In: Honey: A Comprehensive Survey (Ed. E. Crane). Heinemann, London, pp. 240-257.

Miele, N. A., Cabisidan, E. K., Plaza, A. G., Masi, P., Cavella, S., \& Di Monaco, R. (2017). Carbohydrate sweetener reduction in beverages through the use of high potency sweeteners: Trends and new perspectives from a sensory point of view. Trends in Food Science \& Technology, 64, 87-93. https://doi.org/10.1016/j.tifs.2017.04.010.

Mohammed, G. A., Makinta, A., Yawuri, B. B., Bassey, E. E., Haroun, F., Marte, U. M., Idris, K. K., \& Samuel, M. (2017). Survey on traditional beekeeping and honey production in biu and its environs, north-eastern Nigeria. International Journal of Environmental Protection and Policy, 5(6-1), 8-16. https://doi.org/10.11648/j.ijepp.s.2017050601.12.

Ndife, J., Abioye, L., \& Dandago, M. (2014). Quality assessment of Nigerian honey sourced from different floral locations. Nigerian Food Journal, 32(2), 48-55. https://doi.org/10.1016/S0189-7241(15)30117-X.

Noor, M. J., Khan, M. A., \& Camphor, E. S. (2009). Palynological analysis of pollen loads from pollen sources of honeybees in Islamabad, Pakistan. Pakistan Journal of Botany, 41(2), 495-501.

Payne, C. L., \& Van Itterbeeck, J. (2017). Ecosystem services from edible insects in $\begin{array}{llll}\text { agricultural } & \text { systems: } & \text { A } & \end{array}$ https://doi.org/10.3390/insects8010024. 
Pohl, P., Stecka, H., Sergiel, I., \& Jamroz, P. (2012). Different aspects of the elemental analysis of honey by flame atomic absorption and emission spectrometry: A review. Food Analytical Methods, 5(4), 737-751. https://doi.org/10.1007/s12161011-9309-y.

Sajid, M., Yamin, M., Asad, F., Yaqub, S., Ahmad, S., Mubarik, M. A. M. S., Ahmad, B., Ahmad, W., \& Qamer, S. (2020). Comparative study of physio-chemical analysis of fresh and branded honeys from Pakistan. Saudi Journal of Biological Sciences, 27(1), 173-176. https://doi.org/10.1016/j.sjbs.2019.06.014.

Terrab, A., Díez, M. J., \& Heredia, F. J. (2002). Characterisation of Moroccan unifloral honeys by their physicochemical characteristics. Food Chemistry, 79(3), 373-379. https://doi.org/10.1016/S0308-8146(02)00189-9. 